KATARZYNA KośĆ-RYŻKO

Instytut Archeologii i Etnologii PAN, Warszawa

\title{
Inicjacje terenowe i rozwojowy wymiar doświadczania „pola badawczego". Opowieści o wojnie, zesłaniu i terenowym modus operandi
}

\section{Wprowadzenie}

Każde badanie etnograficzne to podróż. Nie zawsze w sensie dosłownym, Kchoć tak się na ogół kojarzy. Poza geograficznym i transkulturowym wymiarem peregrynacji, istnieje jeszcze mniej oczywisty wymiar - dzięki autoetnografii chętnie, od pewnego czasu eksplorowany - mianowicie wymiar introspekcyjnych wypraw w głąb siebie i własnego „pola badawczego", oglądanego i analizowanego z określonego dystansu. Jeszcze do niedawna normą było pozostawanie badacza w ukryciu; tak jakby jego osoba - jej wyjątkowość i niepowtarzalność - nie miała najmniejszego znaczenia dla efektu prowadzonych studiów ${ }^{1}$. Jak pisze Joanna Bielecka-Prus, to „samowykluczenie” [badacza dop. KKR] z narracji pełniło istotną funkcję: z jednej strony dawało złudną gwarancję obiektywności wyników badań, z drugiej zaś umieszczało antropologa na cokole niezłomnego odkrywcy" (Bielecka-Prus 2018: 81). Od pewnego czasu następuje jednak zasadnicza zmiana perspektywy, w której opisowi procedury badawczej często towarzyszy autorefleksyjna eksploracja własnego działania i funkcjonowania w terenie. Analiza osobistego procesu rozwojowego staje się

\footnotetext{
${ }^{1}$ Do niedawna ideałem procesu badawczego prawidłowo zoperacjonalizowanego i skonceptualizowanego (również w ramach nauk społecznych zapatrzonych w metody ilościowe) była jego powtarzalność, zapewniająca możliwość replikacji w innym czasie i przy innych zmiennych.
} 
nie mniej istotna niż meritum projektowe i jego opis. Pomimo że nie wszyscy badacze odnajdują się w tym "nowym" stylu, bazującym na retrospektywnym wglądzie w etnograficzną jaźń (do czego wrócę w zakończeniu), to na ogół ta właśnie perspektywa nie budzi już zaskoczenia i spotyka się coraz częściej ze zrozumieniem. Jej celem jest nie tylko pełniejsza (i bardziej atrakcyjna w treści) tekstualizacja doświadczeń terenowych, ale i dostrzeżenie, że to ważny element procesu badawczego $\mathrm{w}$ jego najczystszej formie (por. Kacperczyk 2014). Obecność badacza w terenie to pierwszy krok prowadzonych studiów, a kolejne najczęściej są wypadkowymi takich jego cech, jak: umiejętność wchodzenia $\mathrm{w}$ relacje, sposoby budowania zaufania, zdolność słuchania, empatii i prowadzenia zaangażowanej rozmowy nakierowanej na partnera interakcji. Wszystkie one wpływają bezpośrednio na jakość zebranych danych i często okupione są dużym wysiłkiem psychicznym, bowiem „pole badawcze [...] nie jest zamkniętym pudełkiem, do którego etnografowie wchodzą, ale areną zmagań, negocjowania celów i pracą nad emocjami" (Bielecka-Prus 2018: 87). Przyznanie się do trudności w terenie, do własnych słabości i porażek, a nawet do zwątpienia w sens działań badawczych, wymaga odwagi zarówno wobec siebie, jak też własnego środowiska zawodowego. Upublicznianie ich nie służy wyznaniu win, ale krytycznemu oglądowi warsztatu pracy, rozpoznaniu problemów i poszerzaniu horyzontów wiedzy wykraczających poza wskazówki udzielane przez podręczniki metodologiczne. Przede wszystkim jednak, jak celnie puentuje J. Bielecka-Prus: „[...] prace autoetnograficzne to przydatne vademecum, pokazujące, jak metodologiczne procedury pracują $\mathrm{w}$ terenie badawczym, we właściwym dla nich kontekście" (Bielecka-Prus 2018: 99). Im trudniejszy teren, tym na ogół więcej wyzwań nie tylko warsztatowych i metodologicznych, ale również psychologiczno-osobowościowych. Ich spektrum jest kwestią indywidualną, wpisaną w biogram każdego badacza; niemniej, jak pokazała chociażby publikacja zapisków i notatek Bronisława Malinowskiego² i towarzysząca im dyskusja, potrzeba identyfikacji i przełamania zmowy milczenia na ten temat była w środowisku bardzo silna. Ujawnianie swoistego modus operandi to zresztą nie tylko domena etnologów. Nie bez powodu wielkim zainteresowaniem cieszą się wszelkiego rodzaju dzienniki, wspomnienia i biografie ludzi, którzy w istotny sposób wpłynęli na kształt obecnego świata (polityków, artystów, uczonych, społeczników, celebrytów). Potrzeba zrozumienia, jak doszli oni do pewnych ważnych wniosków, czy też jakie wydarzenia wpłynęły na to, kim się stali, wynika nie tylko z ciekawości i fascynacji, ale także z poszukiwania inspiracji.

Pracując $w$ wymagającym interakcyjnie i niepoddającym się łatwo obróbce interpretacyjnej terenie, szybko można dojść do konkluzji, że to, w czym dostrzegamy swój wkład, nie jest wyłącznie monografią naukową, z nami w roli autorów, ale namacalną rzeczywistością i prawdziwym życiem; czasami bowiem zapominamy, że mamy w nim współudział (chociażby przez wkroczenie w intymną

\footnotetext{
${ }^{2}$ Mam na myśli Dziennik w ścistym znaczeniu tego wyrazu (wyd. pol. 2008).
} 
przestrzeń doświadczeń naszych rozmówców). Na usprawiedliwienie warto dodać, że nie zawsze wiadomo, czego można się spodziewać w danym polu badawczym. Gdy jednak można to przewidzieć, w planowaniu takiej „podróży” niezbędne staje się uwzględnienie potencjalnego ryzyka i wzięcie za nie odpowiedzialności. Nie chodzi przy tym o moralizowanie, ale o zwrócenie uwagi na te momenty doświadczenia terenowego, które mogą okazać się ważniejsze niż sam proces badawczy i standardowo pełnione w jego trakcie role. Kumulowane na przestrzeni lat przeżycia i „olśnienia” stanowią nierzadko istotne punkty zwrotne w trajektorii indywidualnej biografii badacza, konstytuujące jego tożsamość. W pewnym sensie są więc inicjacjami stwarzającymi "człowieka”, który za ich sprawą „staje się”, dojrzewa, pokonuje kolejne stadia rozwojowe (por. Arnett 2007: 14-15).

Być może przedstawiciele innych dyscyplin „tworzących literaturę” są pod tym względem w nieco lepszej sytuacji. Mniej spętani konwenansem eksploracji naukowych i zwyczajowej ortodoksji stylistyczno-narracyjnej, mogą sobie pozwolić na bardziej śmiałe opisy własnych doświadczeń w terenie, a niekiedy nawet na eksponowanie ,ja” bez skrępowania. Dotyczy to także przedstawicieli nurtu literatury non-fiction, śmiało wdzierających się w rewiry do niedawna dostępne głównie antropologom. Ich wędrówki „po terenie” różnie bywają motywowane, rzadko jednak są tak expressis verbis nieposkromione przez nobilitowaną na tę okoliczność skromność, jak w wypowiedzi „króla” polskiej szkoły reportażu:

Mówiąc o podróży, nie mam oczywiście na myśli turystycznej przygody. W naszym reporterskim rozumieniu podróż to wyzwanie i wysiłek, mozół i poświęcenie, trudne zadanie, ambitny projekt do wykonania. Podróżując, odczuwamy, że dzieje się coś ważnego, że uczestniczymy w czymś, czego jesteśmy jednocześnie świadkami i twórcami, że spoczywa na nas obowiązek, że jesteśmy za coś odpowiedzialni (Kapuściński 2006: 12).

Nietrudno dostrzec w cytowanym fragmencie wiele podobieństw z etnograficznymi zmaganiami z terenem mniej explicite wyrażanymi. Może więc autoetnografia (jako metodologia i epistemologia) jest próbą (re)humanizacji pozytywistycznie rozumianej empirii, oddzielonej od "ciała, ducha i zmysłów", sprowadzonych do roli pośredników, a czasami nawet dystraktorów w procesie poznania. Dorzucając swoją „cegiełkę” do rozważań z pola badawczego (i o polu badawczym), które stają się czasami „polami walki” z własnymi ograniczeniami, chciałam podzielić się z czytelnikami swoimi dylematami i trudnościami towarzyszącymi mi przy realizacji jednego z pierwszych podejmowanych zawodowo tematów, który równocześnie stał się moim „inicjacyjnym” polem. Dlaczego? spróbuję wyjaśnić w dalszej części tekstu. 


\section{Badania prowadzone wśród ofiar wojen}

Wspólną cechą prowadzonych dotychczas przeze mnie badań jest transgresyjny charakter przeżyć opisywanych przez ludzi; a często nawet ich ekstremalny, graniczny (w rozumieniu Jaspersa ${ }^{3}$ ) wymiar (Jaspers 1978; por. Kolasa 2010: 136-137). Podejmując się różnych tematów, zamierzałam dowiedzieć się, w jaki sposób tragiczne doświadczenia, takie jak wojna, deportacja, migracja, uchodźstwo, przemoc i obcowanie ze śmiercią, wpływają na życie jednostkowe, społeczne oraz na zmiany kulturowe ${ }^{4}$. W tym artykule skupię się na omówieniu jednego ze wspomnianych pól badawczych, przy czym w pewien (nieoczywisty) sposób łączy się ono z kolejnymi tematami, podejmowanymi przeze mnie w okresie późniejszym; zwłaszcza z ostatnimi projektami realizowanymi od 2009 r., a dotyczącymi sytuacji społeczno-kulturowej i tożsamości uchodźców zamieszkałych w Polsce 5 .

Problematyka, na której tutaj się skupię, obfitowała w rozliczne dylematy etyczne i wyzwania terenowe, które ponadto miały silny i formujący wpływ na moją obecną perspektywę badawczą. W tytule tekstu używam sformułowania "rozwojowa rola", chcąc zaakcentować poniekąd oczywisty fakt, że „dorastamy" $\mathrm{i}$ "dojrzewamy” w terenie. Chodzi między innymi o to, że wiedza (o świecie i rządzących nim prawach, a w moim przypadku o trudnych doświadczeniach i sposobach radzenia sobie z nimi) zdobywana nie wprost, ale za pośrednictwem naszych rozmówców, kształtuje nas nie tylko zawodowo, ale też osobowościowo. Te okoliczności czasami sprawiają, że dzięki nim wchodzimy w orbitę spraw, których w normalnych warunkach (innych niż praktyka zawodowa, badawcza) nie mielibyśmy szans doświadczyć; dostarczają możliwości „życia równoległymi życiami", a jeszcze częściej „w równoległych światach” (wynikających z odmienności kulturowej). Na tym polega niewątpliwy atut, ale też wyzwanie naszej dyscypliny i możliwość „bycia etnologiem”. Rodzi to, oczywiście, określone

\footnotetext{
${ }^{3}$ Sytuacje graniczne, $\mathrm{w}$ rozumieniu Jaspersa, to doświadczenia wybijające się z codziennej rutyny i bezrefleksyjnego bycia. Jego zdaniem, przeżycie takich sytuacji powoduje, że człowiek staje się sobą, przez to, że uświadamia sobie i zaczyna odczuwać własną egzystencję; pozwala to uzyskać wgląd we własne życie. Zdaniem badaczy myśli tego filozofa, „[...] przeżywanie sytuacji granicznych stwarza jedyną w swoim rodzaju okazję, by ze świata spraw codziennych wznieść się na szczyt możliwości bycia sobą. Deklaracji tej nie należy rozumieć w sposób metafizyczny [...]" (Kolasa 2010: 138). Do najczęściej wymienianych sytuacji granicznych należą: śmierć, walka, cierpienie, wina. Powodują one uświadomienie sobie historyczności indywidualnego bytu empirycznego, jego kruchość i skończoność (Rudziński 1980: 16-17).

${ }^{4}$ Wymienione kategorie opisują umownie środowiska, wśród których prowadziłam badania. Większość $\mathrm{z}$ nich realizowałam $\mathrm{w}$ ramach projektów finansowanych z grantów KBN, NCN i IAE PAN.

${ }^{5}$ Badania $\mathrm{w}$ środowisku uchodźczym prowadziłam $\mathrm{w}$ ramach grantów przyznanych przez NCN. W latach 2009-2013 razem z dr Izabelą Czerniejewską realizowałyśmy projekt pt. „Dzieci i młodzież uchodźcza w Polsce. Identyfikacja etniczna i kulturowa w perspektywie antropologicznej”, nr NN 109218136, a w latach 2014-2019, już samodzielnie, projekt pt. „Autopercepcja kobiet uchodźczyń w Polsce w kontekście stereotypów i tradycyjnych ról płciowych i ich wpływ na tożsamość oraz adaptację kulturową", nr UMO-2014/15/B/HS3/02462 (por. Kość-Ryżko 2013b, 2015, 2016, 2019; Kość-Ryżko, Czerniejewska 2013a).
} 
konsekwencje; tutaj skupię się przede wszystkim na ich psychologicznych (emocjonalnych, poznawczych, osobowościowych) wymiarach. Etnolodzy konfrontują się z rozmaitymi trudnościami, sprawianymi przez "pole badawcze” i własne ograniczenia, którym próbują samodzielnie sprostać, nie zawsze w pełni zdając sobie sprawę z ponoszonych kosztów i wysiłku, jakiego wymaga radzenie sobie z wpisanymi w tę pracę warunkami: dysonansem, niepewnością, lękiem, znudzeniem, poczuciem obcości i nieadekwatności, samotnością, bezradnością i bezsilnością. Dla każdego ta lista będzie wyglądać nieco inaczej. Historia i praktyka naszej dyscypliny tak się jednak ułożyły, że właściwie do czasu zwrotu literackiego ${ }^{6}$ nie artykułowano bolączek głośno, żeby nie powiedzieć, „nie rozczulano się nad sobą", chcąc zachować empiryczny obiektywizm w jego pozytywistycznym rozumieniu. Tak więc, nie rozwinięto systemu profesjonalnego wsparcia, analogicznego do tego, jaki na przykład pełni superwizja ${ }^{7} \mathrm{w}$ zawodach "zaufania publicznego", opartych na bliskiej relacyjnie pracy z ludźmi, takich jak psycholodzy, pracownicy socjalni, doradcy i terapeuci ${ }^{8}$ (por. Hawkings, Shohet 2006). Zastąpił go swoisty „model samopomocy”, jakim stał się nurt refleksyjny $\mathrm{w}$ antropologii, pełniący nierzadko rolę etnograficznego pisarstwa terapeutycznego (zob. Bielecka-Prus 2018: 83). Oczywiście nie wyłącznie taką rolę, gdyż jego realna funkcja znacznie wykracza poza tę wspomnianą. Tym niemniej wiele wskazuje, że to właśnie trudność funkcjonowania w polu badawczym, a następnie opuszczenia go, sprawiły, że narodziła się potrzeba alternatywnej formy „porządkowania emocji”, „rozwiązywania konfliktów wewnętrznych”, "rozpoznawania ukrytych i sprzecznych potrzeb oraz motywacji”, jakich doznaje etnograf $w$ terenie? . Potrzeba odzwierciedlenia własnych myśli, odczuć i przeżyć jest przy tym wyrazem poszukiwania ich sensu poprzez nadanie określonej treści temu, co nienazwane (por. Szustrowa 2005: 19-20); ponadto jest także ważnym elementem procesu konstruowania tożsamości. Etnograficzna ,jaźń badawcza" przekształca się w wyniku eksploracji terenowych, a zwłaszcza pojawiających się przeszkód. W tym sensie proces ten prowadzi do zmiany, a poprzedza go swoista faza liminalna - określona przez Victora Turnera jako „czas i przestrzeń między dwoma różnymi kontekstami, które wyznaczają ramy znaczeń i działań" (Turner 2005: 188) - nierzadko przypadająca na czas podróży, przebywania w polu

\footnotetext{
${ }^{6}$ Jego data jest umowna, ale przyjmuje się, że nastąpił w latach 70. i 80. ubiegłego wieku, choć jego zwiastunami były już pierwsze dzienniki i biografie etnograficzne pod koniec XIX $w$.

7 Superwizja, to rodzaj spotkań konsultacyjnych z doświadczonym mentorem, podczas których pracuje się nad jakością swojej pracy. Polega ona na omawianiu trudności, ustalaniu celów, sposobów ich realizacji i wspólnym poszukiwaniu dróg rozwoju. Nierzadko jest to także odkrywanie nieuświadamianych uczuć i motywacji towarzyszących realizowanym zadaniom (por. Kadushin, Harkness 2014: 2-3).

${ }^{8}$ Wspominałam już o tym przy okazji innego artykułu dotyczącego psychologicznych wyzwań w pracy etnologa (por. Kość-Ryżko 2013: 18-19).

9 To oczywiście nie wszystkie możliwe symptomy, które można zdiagnozować u etnografów mających syndrom "kryzysu terenowego lub postterenowego", borykających się z potrzebą konceptualizacji tego, w czym uczestniczyli i określenia swojej w tym roli (koniecznej do zakończenia procesu badawczego).
} 
badawczym i wyłączenia się z codziennych, zwyczajnych aktywności. To również sprawia, że etap ten może być porównany do inicjacji ${ }^{10}$.

W trakcie swojej pracy badawczej kilkakrotnie znalazłam się w sytuacjach, które zaliczyć mogłabym do „doświadczeń inicjacyjnych” - stanowiących istotne punkty zwrotne w dotychczasowym postrzeganiu rzeczywistości i podejściu do zawodu. Pełnią one ważną, choć trudną rolę, jako kryzysowe momenty dające asumpt do zmiany rozwojowej ${ }^{11}$. W moim przy padku miały one również pedagogiczny wymiar, gdyż wiele się dzięki nim nauczyłam - i nie mam tutaj na myśli wyłącznie zagadnień mieszczących się w zakresie realizowanego tematu studiów. Spośród prowadzonych przeze mnie projektów, bez wątpienia jednym z najbardziej wymagających, a równocześnie obfitujących w trudne i niejednoznaczne sytuacje generujące rozliczne dylematy, był ten, który wiązał się z moją rozprawą doktorską. Dotyczyła ona podejścia Polaków do śmierci oraz desakralizacji życia w warunkach zesłania w głąb ZSRR, w latach 1940-194612.

Podczas jego realizacji spotykałam się z ludźmi, którzy przeżyli wywózkę i dehumanizujące warunki osiedlenia w Związku Sowieckim (na Syberii, w Kazachstanie i Uzbekistanie) $)^{13}$. Rozmawiałam z nimi o okolicznościach, w których konali ich bliscy - pozbawieni elementarnej pomocy medycznej, wsparcia duchowego i możliwości godnego pochówku. W wielu przypadkach osoby te zostały osierocone w bardzo młodym wieku, straciły biskich, którzy ginęli na ich oczach, w tragicznych okolicznościach; pozostawili swych bliskich pogrzebanych w „obcej ziemi”, i samotnie powrócili do zmienionego kraju ${ }^{14}$. Ogrom żalu i niepogodzenia się z własnym życiem, który wypływał z ich opowieści, przerósł moje wyobrażenia. W najmniejszym stopniu nie zdawałam sobie sprawy, że pytania o wydarzenia sprzed kilkudziesięciu lat wyzwolą taką lawinę bólu

10 Analogia ta została dostrzeżona także $\mathrm{w}$ ramach psychologii rozwojowej, gdzie ukształtowała się koncepcja „stającej się dorosłości” (Arnett 2007); zainspirowały ją rozważania Victora Turnera na temat środkowej fazy rytuału przejścia (por. Lipska, Zagórska 2011).

${ }^{11}$ Można się w tym miejscu zastanawiać, czy każda zmiana i doprowadzający do niej kryzys są rozwojowe. Nie trudno bowiem wyobrazić sobie sytuację, gdy napotkane trudności są zbyt przytłaczające, a pokonana przez nie jednostka wycofuje się i porzuca podjętą działalność. Aby jednak inicjacja była procesem ukończonym, doprowadzającym do twórczego i kreacyjnego przekształcenia, muszą zaistnieć wszystkie jej fazy, łącznie z bolesnym „uśmierceniem” starego-Ja. Tym samym można założyć, że nie każde „trudne doświadczenie” spełnia niniejsze warunki. Przeciwnie - tylko nieliczne z nich i częstokroć okupione największym poczuciem straty, które właściwie ocenić można dopiero z odpowiedniego dystansu i po upływie czasu.

12 Pracę doktorską pod tytułem „Kulturowo-religijny wymiar śmierci w relacjach Polaków deportowanych do ZSRR w latach 1940-41" pisałam pod kierunkiem prof. Antoniego Kuczyńskiego i obroniłam w 2006 r. na Uniwersytecie im. Adama Mickiewicza w Poznaniu (Kość 2008). ${ }_{13}$ Przedmiotem analizy były wybrane zagadnienia opisane $\mathrm{w}$ relacjach, ze szczególnym uwzględnieniem: stosunku zesłańców do chorych, umierających i zwłok w czasie przesiedlenia; wpływu kulturowych wzorów i norm postępowania w obliczu śmierci; sposobów radzenia sobie z następstwami doświadczonej traumy po powrocie do kraju.

${ }^{14}$ Celem było m.in. poznanie wpływu kontekstu kulturowego i religijnego na kształtowanie się przekonań i zachowań wobec konania i zgonu. Zależało mi na poznaniu praktyk i sposobów funkcjonowania w obliczu permanentnie doświadczanej bliskości śmierci w ekstremalnych warunkach (skazujących ludzi na desakralizację życia i jego kresu oraz reifikację ludzkich szczątków). 
i dramatycznych wspomnień. Kilkakrotnie zdarzyło się, że starsi mężczyźni i kobiety, powracając pamięcią do tamtych chwil, stawali się bezbronni, rozdygotani i spłakani jak małe dzieci. Ja zaś nie wiedziałam, co w tej sytuacji począć - jak im pomóc, jak sobie pomóc i czy wolno mi wprowadzać ich w takie stany emocjonalnego rozstroju. Nie ukrywam, że towarzyszyło mi ogromne poczucie winy oraz liczne wątpliwości - i nie były to jedyne emocje, które wtedy przeżywałam. Studiując równocześnie psychologię, byłam w o tyle komfortowej sytuacji, że mogłam się wówczas poradzić moich wykładowców, co robić w takiej sytuacji i jak dalej postępować. Po długich rozmowach podjęłam decyzję o zmianie formy pozyskiwania danych na bardziej poddającą się kontroli i nierodzącą tylu wątpliwości, nie rezygnując przy tym z przyjętej metody narracyjnej. Było to możliwe dzięki dostępności niepublikowanych relacji zesłańczych i materiałów archiwalnych, które uzupełniałam bezpośrednio przeprowadzanymi rozmowami. Jakkolwiek literatura naukowa intensywnie eksploruje motyw uzdrawiającej roli wspomnień i narracji autobiograficznych, to ich działanie terapeutyczne nie polega na swobodnym i niekontrolowanym uwalnianiu zasobów pamięciowych (por. Demetrio 2000). Wywoływanie ukrytych i wypartych treści ludzkiej psychobiografii jest procesem znacznie bardziej skomplikowanym niż może się wydawać (McKinley Runyan 1992: 86-88). Szkody psychiczne wyrządzone nierozważnym „odmrażaniem” bolesnych wspomnień i emocji mogą być znaczne. Dlatego troska o dobrostan psychologiczny informatorów powinna być zawsze brana pod uwage w rozmowach i wzajemnych interakcjach ${ }^{15}$.

W przypadku praktyki psychologicznej zasady etyki zawodowej szczegółowo instruują o trybie postępowania w sytuacji przepracowywania traumy z pacjentem. Podstawową zasadą jest, aby nie zostawiać go samego z wywołanymi z przeszłości urazowymi wspomnieniami, ale by go umiejętnie przeprowadzić przez ten etap trudności (por. Levine 2017). Nadrzędnym celem pracy psychologicznej i terapeutycznej nie jest jednak „wywoływanie wspomnień” $\mathrm{i}$ „ppozyskiwanie informacji o przeszłości danego człowieka”, ale pomoc w odzyskaniu stabilności emocjonalnej i kontroli nad własnym życiem. Jest to zasadnicza różnica w etnograficznym działaniu badawczym i psychologicznym. Na tej podstawie sądzę, że w większości przypadków etnolodzy nie są profesjonalnie przygotowani do pracy w tak delikatnej materii, jak „psychika ludzka”. Lecz czy muszą być? Dominująca część z nich to wrażliwi i empatyczni słuchacze, i na ogół przymioty te są wystarczające dla pozyskania interesującego, wartościowego materiału podczas badan terenowych. A jednak, nie zaszkodziłoby, aby standardowa ścieżka kształcenia antropologów zawierała podstawowy kurs psychologii ogólnej lub społecznej ${ }^{16}$.

15 Zdaję sobie sprawę, że czasami trudno uniknąć „wybicia informatorów ze strefy komfortu” i to też może być elementem pracy badawczej lub techniką pozyskiwania danych.

${ }_{16}$ Wspominałam o tym w kilku artykułach i przy okazji wystąpień konferencyjnych, więc nie będę ponownie przytaczać tych samych argumentów. W przypadku nauki stawiającej w centrum swych badań człowieka i jego kulturę, poszerzenie spektrum poznania o wymiar psychologiczny wydaje się logicznie uzasadnione (por. Kość-Ryżko 2013 c, d). 


\section{Rozmowy o śmierci, zesłaniu i tramie wojennej}

Gdy przystępowałam do badań poświęconych zasygnalizowanemu wyżej tematowi, wydawało mi się, że jestem do niego nie najgorzej przygotowana. Przez dwa wcześniejsze lata zbierałam materiały dotyczące śmierci i związanych z nią praktyk w kulturze współczesnej, gdyż początkowo tym zagadnieniom miała być poświęcona moja dysertacja. Dzisiaj wiem, że miałam niewielkie pojęcie o tym, czego się podejmowałam. Było to chyba kluczowe dla trudności, z jakimi musiałam się później zmierzyć w terenie oraz po jego opuszczeniu. Wbrew swoim początkowym obawom, nie miałam żadnych kłopotów z dotarciem do rozmówców. Większość z nich stanowiły osoby w zaawansowanym wieku lub nawet zdające sobie sprawę, że są u kresu życia. To przyczyniło się, jak sądzę, do ich otwartości na spotkanie i rozmowę. Stąd wypływał mój optymizm, który rychło okazał się przedwczesny. Powodów było kilka. Po pierwsze, badani chcieli opowiadać, ale na ogół na każdy inny temat niż ten, który mnie interesował ${ }^{17}$. Niektórzy wręcz wymagali obietnic, że wysłucham i opiszę wszystko, co mają mi do powiedzenia. Oczywiście nie mogłam tego obiecać, co czasami rodziło ich rozczarowanie i prowokowało do nieprzyjemnych komentarzy. Poza tym wywiady trwały długo, przeciągały się i były angażujące emocjonalnie. Po drugie, nawet gdy udawało się je przeprowadzić bez zbyt dalekiego odbiegania od tematu, często pojawiały się łzy, a przytłaczające historie prowadziły do przygnębiających konkluzji o życiu. Miałam poczucie, że proces ten czasami przypomina niebezpieczne "balansowanie na cienkiej linie" i bałam się, że może otworzyć zasklepione rany, przywołać traumy, na co zupełnie nie byłam przygotowana.

Po trzecie, ci, którzy godzili się na rozmowę dotyczącą trudnych przeżyć i mówili o nich barwnie, i z przejęciem, często płacili za to wysoką cenę - pogarszało się ich samopoczucie, podupadali na zdrowiu. Nie mogłam na to przystać, a ponadto pojawił się kolejny problem. Zdarzało się, że ludzie ci nie chcieli rezygnować ze spotkań ze mną i możliwości wspominania przeszłości; tymczasem od członków ich rodzin słyszałam odmienne sugestie, w rodzaju: „Proszę już więcej do nas nie dzwonić. Mama źle znosi rozmowy na ten temat. Ostatnio nie mogła spać. Znowu pojawiły się problemy z sercem i ciśnieniem”; albo: „Jak pani może! Nie widzi pani, że mama płacze. Nie wolno o takie rzeczy pytać!". Raz zdarzyło się nawet, że nie miałam okazji pożegnać się z moim rozmówcą i wytłumaczyć, dlaczego nie będziemy kontynuować naszych rozmów, ponieważ telefon odebrał jego syn, oświadczając: „Dla dobra tatusia nie mogę mu przekazać, że pani dzwoniła. Myślę, że powinna to pani zrozumieć".

Byłam zdziwiona oporem przed poruszaniem tematu deportacyjnych przeżyć, z jakim się zetknęłam ze strony członków rodzin Sybiraków. Sami zesłańcy

\footnotetext{
${ }^{17}$ Jednak to również ciekawy wątek, zasługujący na osobne omówienie; odniosłam wrażenie, że wielu rozmówców dręczyło poczucie winy, że wcześniej milczeli i chcieli nadrobić ten czas. Inni zaś mieli potrzebę wytłumaczenia się ze swojego życia, które w ich poczuciu było nieudane albo za sprawą utraconej młodości i zdrowia, albo z powodu podejmowanych kompromisów i ukrywania zesłańczej przeszłości.
} 
byli znacznie bardziej przychylni rozmowom niż ich krewni. Dopiero po pewnym czasie skojarzyłam podobieństwo tego zachowania z syndromem dziedziczonej traumy holocaustu (tzw. second-generation Holocaust survivors' trauma) (Juni 2017). Jednak trudno mi było zrozumieć, dlaczego przez tyle lat nikt nie rozmawiał z tymi ludźmi na temat ich dramatycznych przeżyć: wczesnodziecięcego osierocenia, uczestniczenia z zgonach bliskich osób, obserwacji ich ciężkiego konania i bezczeszczenia zwłok, samotnego życia w sowieckich sierocińcach, powrotu do zmienionej ojczyzny, przemilczania ich tragicznych losów oraz zakłamywania historii, która była również prywatną historią ich życia. Mimo to uważałam, że to zbyt delikatna materia, aby ryzykować wyrządzenie swoją „badawczą ciekawością" szkody ludziom, którzy i bez tego przeżyli tak wiele zawodów. Zburzenie ich spokoju, jakkolwiek kruchego i prowizorycznego, mogło być dalekie od tego, co się potocznie nazywa „uzdrawiającą mocą wspomnień” czy też terapeutyczną funkcją narracji (Tokarska 2002: 240-244).

Wątpliwościom towarzyszył również dylemat moralny - ulec pokusie korzyści badawczych i kontynuować rozmowy z bezpośrednimi świadkami zdarzeń czy - uwzględniając ich dobrostan - wycofać się z tego zadania. Ponieważ wkrótce katalog wyzwań etycznych zaczął się niepokojąco wydłużać, podjęłam decyzję (przyznam, że z wielka ulgą) o zupełnej zmianie metodologii i częściowej rezygnacji z bezpośrednich rozmów o śmierci z byłymi zesłańcami, ale nie z kontaktów z nimi. Połowicznym rozwiązaniem było także uczestniczenie w zbiorowych spotkaniach Sybiraków, podczas których chętnie sięgali oni do bogatego repertuaru wspomnień, nierzadko serdecznie się przy tym wzruszając, ale nie ulegając niepokojącej i niekontrolowanej afektacji. Mogłam wtedy również pytać o sprawy, które mnie interesowały, wiedząc, że odpowiedzą tylko ci, którzy mają ochotę albo ewentualnie zmienią temat, na co będę musiała przystać.

W przypadku opisywanego pola badawczego jednym z głównych wyzwań było znalezienie sposobu na rozmawianie z ludźmi o tym, o czym nie chcą rozmawiać i o czym przez całe życie próbowali zapomnieć. W konsekwencji towarzyszyło mi poczucie, że bezceremonialnie wchodzę w obszar cudzego cierpienia, tak jakby wzgląd na „poznanie naukowe” dawał mi na to przyzwolenie i był wystarczającym uzasadnieniem. Podejście takie umniejszało znaczenie poniesionych przez zesłańców strat i ich intymnych przeżyć, sprowadzając je do rangi naukowego „eksponatu”, a ich samych - do roli uczestników eksperymentu badawczego. Bez większych wątpliwości zdecydowałam się, że takie podejście jest trudne do zaakceptowania i usprawiedliwienia. W końcu udało mi się wielu opisanym tutaj dylematom w jakiś sposób zaradzić i zrealizować pomyślnie projekt, którego efektem stała się monografia i kilka mniejszych publikacji (Kość-Ryżko 2008; 2013). Nie znaczy to jednak, że zmiana metodologii i źródeł badawczych rozwiązała wszystkie problemy związane z samym tematem. Dlatego też w kolejnym fragmencie tego szkicu wspomnę o kilku sytuacjach, które obrazują zupełnie inny rodzaj wyzwań, jaki może stanowić etnograficzny "teren” - nawet, gdy jest nim archiwum i spisane narracje biograficzne. 


\section{Narracje z zesłania i opisywanie przeżyć nie-do-opisania}

Specyfiką analizowanych wspomnień było to, że większość z nich stanowiły źródła wywołane, powstałe $w$ odzewie na konkursy ogłaszane przez różne instytucje po 1989 r. Największy ich zbiór, zgromadzony we wrocławskim Archiwum Polskiego Towarzystwa Ludoznawczego, składa się z ponad 400 dokumentów liczących ponad 60 tysięcy stron. Część z nich została wydana w ramach serii „Biblioteka Zesłańca"18. Wśród relacji nadsyłanych na konkursy znalazły się również spisane wcześniej pamiętniki, diariusze, czasami ich fragmenty, a także zdjęcia i dokumenty osobiste, które skrzętnie przechowywano przez kilkadziesiąt lat. Różnica między wspomnieniami odtwarzanymi z pamięci, i uzupełnianymi późniejszą wiedzą oraz zasłyszanymi od innych informacjami, a notatkami spisywanymi na miejscu zesłania, była bardzo duża. Te pierwsze były często fabularyzowane, zawierały dużo opisów, miały wyraźne tło historyczne i swoistą dramaturgię; drugie zaś były na ogół nierównomierne pod względem treści, surowe $w$ formie, często lakoniczne, ale zawierały opisy emocji towarzyszących różnym wydarzeniom i szczegóły mające istotne znaczenie przy interpretacji psychologicznej. Zdecydowana większość wspomnień powstała po kilkudziesięciu latach od wywózki, po przemianach ustrojowych, które umożliwiły odtajnienie wielu dotychczas ocenzurowanych kart historii Polski. Fakt ten odbił się również, w jakimś stopniu, na treści owych relacji; na przykład na różnorodności wątków dotyczących stosunków polsko-sowieckich, ocenach sytuacji politycznej oraz na ogólnej interpretacji odległych wydarzeń. Wadą tych materiałów i zarazem pułapką metodologiczną był jednak częsty wśród ich autorów kreacjonizm, polegający między innymi na kontrolowanym opisie zdarzeń, dostosowywaniu treści do oczekiwań czytelników oraz autoprezentacji zmierzającej do zdobycia aprobaty społecznej. Nierzadkie były wspomnienia stylizowane i dramatyzowane, odwołujące się do pewnych konwencji narracyjnych, na przykład zawierające dialogi, wplecione historie, anegdoty itp.

Jednym z dylematów, którym musiałam stawić czoła, podejmując się opracowania tych materiałów, była decyzja, jak je traktować - literalnie jako dokumenty osobiste czy raczej literacko, jako rodzaj twórczego przetworzenia zachowanych w pamięci wspomnień, a może jako źródło biograficzne świadczące o indywidualnych zmaganiach z dojmującą przeszłością. Kolejną wątpliwością było to, jak pisać o sprawach tak trudnych, że aż „nie-do-opisania” (o tych wszystkich stratach, traumach, rozczarowaniach i wyobcowaniu), aby nie popaść w banał i egzaltację lub przeciwnie - $\mathrm{w}$ patos $\mathrm{i}$ ton martyrologiczny lub co gorsza $\mathrm{w}$ zdystansowaną,

${ }_{18}$ Spory zbiór zgromadziło również Archiwum Wschodnie Ośrodka „Karta”, Muzeum Niepodległości w Warszawie (w ramach „Kolekcji Sybirackiej”), Miejska Biblioteka Publiczna w Łodzi (Polesie) w ramach „Zbiorów Biblioteki Sybiraka”, Archiwum Naukowe Związku Sybiraków w Kielcach oraz Archiwum Naukowe Związku Sybiraków w Warszawie. Na podstawie zbiorów tego ostatniego ukazało się kilka tomów Wspomnień Sybiraków pod redakcją Janusza Przewłockiego (Wspomnienia Sybiraków, t. 1-14, 1989-2008 oprac. J. Przewłocki, wyd. Związek Sybiraków. Zarząd Główny. Komisja Historyczna, Warszawa: „Pomost”, „Ares”). 
chłodną narrację w bezosobowym socjolekcie. Sformułowania „nie-do-opisania” używam więc w dwoistym sensie: jako dotyczącego trudności ze znalezieniem właściwych słów do opisu wojennych przeżyć oraz jako oznaczającego wydarzenia i sprawy, o których się nie mówi, gdyż są objęte tabu i nakazem milczenia. Wbrew pozorom znalezienie właściwego rozwiązania nie było proste. Ostatecznie postanowiłam nie ingerować w treść i styl relacji, umiarkowanie je komentować i milczeć wobec głosów, które „mówią same za siebie”. Rezygnuję z brania nadmiernej odpowiedzialności za to, „jak” mówią autorzy wspomnień, skupiałam się przede wszystkim na tym, „o czym mówią” i co przemilczają. Wstępna analiza relacji skłoniła mnie do tego, aby traktować je kompleksowo, z całym bagażem kontekstów, na które składają się czas, miejsce, okoliczności powstania oraz aktualna sytuacja ich autorów (materialna, rodzinna, zdrowotna). Podejście takie wydało mi się właściwsze niż wyrywkowe analizowanie pojedynczych wątków w sposób faktograficzny, pomijający wymienione uwarunkowania.

Czytając relacje deportowanych, zastanawiałam się, jak można po takich doświadczeniach żyć. Próbowałam zrozumieć, skąd wzięła się w nich siła do pokonywania trudności. Chciałam dowiedzieć się, jak doświadczenia zesłańcze wpłynęły na ich adaptację do nowych warunków po powrocie do kraju oraz jak oceniają własną egzystencję z perspektywy czasu. Miałam naiwną nadzieję, że poznam jakąś „tajemnicę ich życia”, która będzie zawierała uniwersalną prawdę o kondycji ludzkiej, o zdolnościach do przetrwania w zdehumanizowanych warunkach (resilience - zob. Cyrulnik 2009). Tymczasem w obliczu tego, z czym się zetknęłam, wyzwaniem był już sam język, nieprzystosowany do opisu takich sytuacji (czasami nieporadny, czasami obcesowy lub górnolotny). Kluczem do większości podobnych do siebie i powtarzalnych relacji, składających się z opisów różnych epizodów, były narracje wyróżniające się refleksyjnością i znaczącym wglądem w bieg tragicznych doświadczeń. Bez nich trudno byłoby zrozumieć pozostałe opisy - ich schematyczność i powściągliwość emocjonalną, przy równoczesnym epatowaniu brutalnością i zwyrodnialstwem. Wyłaniająca się z nich groza uzmysłowiła mi, że był to jeden ze sposobów radzenia sobie z codzienną realnością wojennych przeżyć, towarzyszących tym ludziom przez długie lata. Dokonywana przez nich fabularyzacja i ekspozycja - nasuwająca skojarzenia z filmem oglądanym tak, jakby dotyczył kogoś innego - pozwalały uwolnić się od prześladujących obrazów wrytych w pamięć. O trudności z przekazem własnych przeżyć wspominało wielu autorów relacji: „Wydarzenia tamtych lat to dla mnie sacrum. Mówię o nich niechętnie. [...] Mam poczucie, że treść przeżyć z tamtych miejsc jest nieprzekazywalna" (Obuchowski 1992: 112).

Zesłańcy wojenni, którzy z różnych względów zdecydowali się opisać swoje przeżycia, mieli prawdopodobnie świadomość, że to, czego doświadczyli, nie było normalne, stąd też ich trudności, by te przeżycia oddać za pomocą zwykłych kategorii pojęciowych funkcjonujących w codziennym języku. Autocenzura chroniła ich przed groźbą kolejnego odrzucenia przez wspólnotę, ale była też wyrazem lęku przed nieakceptacją tego, co złożyło się na drażliwe „piętno zesłańca”. Trud włożony w starania, aby żyć normalnie, był tak duży, że cena zburzenia spokoju 
wydawała się zbyt wygórowana. Tym można tłumaczyć ukrywanie swojej przeszłości przez niektórych zesłańców nawet przed najbliższymi i dopiero publiczna zachęta do spisania wspomnień ośmieliła ich do otworzenia się. Jedna z deportowanych kobiet wspominała o uldze, jaką sprawiła jej możliwość opowiedzenia tego, co przeżyła:

Przez cały czas nigdzie nie można było mówić o tym, że byłam na Sybirze. Na rentę inwalidzką wysłano mnie w $1978 \mathrm{r}$. Byłam silnie znerwicowana ciężkimi przeżyciami w dzieciństwie, a także miałam odmrożenie nóg, rak i twarzy. [...] Piętno tego co przeżyłam będąc na Sybirze pozostanie mi do końca życia. Ja jako dziecko wroga tułałam się po sierocińcach nie znając ani czułości ani żadnej dobroci. Zdana na własne siły już od dzieciństwa musiałam pracować i ocenić dobro od zła. [...] Cieszę się bardzo, że wreszcie mogłam się komuś zwierzyć i opisać swoje przeżycia, takie jakie były prawdziwe nie tając niczego. Wiele się nie pamięta, a o wielu rzeczach się nie wspomina, gdyż łzy cisną się do oczu i zalewają papier. Pisząc swoje wspomnienia pragnę ażeby nasze dzieci i wnuki wiedzieli prawdę o wszystkim i uczyli się tej prawdy w szkołach. Moi synowie a mam ich trzech dopiero teraz widzą co ja i ich dziadkowie przeżyliśmy na zesłaniu w ZSRR na dalekiej Syberii (Puławka 1989: 7).

Jednym z powodów unikania zwierzeń na temat wywózki była sytuacja polityczna w Polsce po II wojnie światowej oraz towarzysząca jej atmosfera podejrzliwości i zastraszenia wobec byłych zesłańców, którą szerzono w rządzonej przez komunistów Polskiej Rzeczpospolitej Ludowej. Obawa przed ujawnianiem szczegółów deportacyjnych doświadczeń świadczyła, że zesłańcy zdawali sobie sprawę, iż powrócili z „nieludzkiej ziemi” (Czapski 1949). Podobną myśl wyraziła jedna z moich rozmówczyń: „,byłam w piekle i nigdy nie zapomniałam tego, co widziałam. Ta wiedza zaważyła na moim podejściu do ludzi i świata"19. W trudniejszej psychologicznie sytuacji znalazły się te osoby, które oswoiły się z zesłańczą patologią i przyzwyczaiły się do niej na tyle, że przestały ją dostrzegać. Sytuację tę uznać można za zgodną z tezą głosząca, że najgorszy los spotykał na zsyłce tych, którzy stawali się jej częścią (por. Obuchowski 2005: 55). Równocześnie jednak wielu zesłańców, pomimo trudności w powrocie pamięciowym do wypartych wspomnień, otwarcie przyznawało, że cieszą się, iż w końcu mogli podzielić się przeżyciami ukrywanymi nawet przed bliskimi. Trudno ocenić, $\mathrm{w}$ jakim stopniu konieczność przemilczania przeszłości wpłynęła na wartość merytoryczną narracji; przypuszczalnie przyczyniła się do ujawnienia skrywanych emocji i niepohamowanej szczerości. Niektórzy zesłańcy twierdzili wręcz, że odczuli ulgę, przelewając na papier własne przeżycia. Twórczy proces budowania narracji pozwalał im w symboliczny sposób rekonstruować własne życie i uzupełnić je o wyparte fragmenty wspomnień, co spełniało rolę swoistego katharsis. Przykładem jest choćby ta wypowiedź:

19 Materiały $\mathrm{z}$ badań, $\mathrm{w}$ archiwum autorki. 
Od paru lat odczuwałem wewnętrzną potrzebę opisania swoich i mojej rodziny przeżyć w czasie deportacji i pobytu na zesłaniu. Myśl ta coraz bardziej mnie nurtowała, ale codzienne troski o byt rodzinny i zmagania w pokonywaniu wszystkich barier życiowych nie sprzyjały napisaniu tak bardzo ważnych, a jednocześnie bolesnych dla mnie i moich bliskich wspomnień. Opisu tego wszystkiego, co jeszcze nie zatarło się w mojej pamięci mogłem dokonać dopiero po przejściu na emeryturę. [...] Ten rozdział historii części naszego polskiego społeczeństwa celowo był przez ówczesne władze przemilczany i stanowił tabu. Przez prawie czterdzieści pięć lat w PRL na ten temat nie wolno było publicznie się wypowiadać (Paluch 1993: 15).

Relacje, które były podstawą analizy wspomnianych wcześniej zagadnień, stanowią biograficzny zapis indywidualnych losów jednostki lub całej rodziny na tle wojny. Zarazem są również jej świadectwem, zgodnie ze stwierdzeniem Kai Kaźmierskiej, że biograficzna narracja o wojnie łączy w sobie wymiar indywidualnego doświadczenia z kolektywnymi wyobrażeniami, zbudowanymi w zbiorowym obrazie przeszłości (Kaźmierska 1999: 11). Specyfika tych świadectw sprawiła jednak, że skoncentrowałam się na uchwyceniu i opisaniu subiektywnego i emocjonalnego postrzegania przez deportowanych śmierci oraz jej oblicza w realiach wywózki, a także na sposobie i formie mówienia o tym. Zwracałam uwagę na to, co autorzy wspomnień pamiętają, jaka jest forma ich relacji, skąd czerpią wzorce narracyjne, oraz jaki wpływ na ich życie wywarły opisane doświadczania.

Analiza relacji, a szczególnie fragmentów odnoszących się do problemów adaptacyjnych po powrocie do kraju, sugeruje, że wielu ich autorów poważnie cierpiało na skutek realnego zagrożenia życia podczas zesłania. Niektórzy z nich doznali urazu w wyniku silnego wstrząsu, wywołanego na przykład przez widok porzuconych zwłok, przez zaspokajanie głodu produktami, które w normalnych warunkach nie są uznawane za jadalne, jak również nieustanne łamanie oczywistych standardów moralnych. Wspomnienia zawierają wiele wypowiedzi sugerujących, że życie zesłańców po powrocie upływało w cieniu deportacyjnych przeżyć. Przykładem są powtarzane niczym refren zdania: „nigdy tego nie zapomnę", "ten obraz na zawsze zostanie w mojej pamięci”, "cały czas mam [go] przed oczami”, "ciągle w uszach brzmią mi [tamte] słowa”, "ten żal mnie nigdy nie opuszcza”, "zesłanie wpłynęło na całe moje życie” itp. Istotnym skutkiem doznanych urazów są trudności z przystosowaniem się do rzeczywistości i funkcjonowaniem w normalnych warunkach. Wypowiedzi zesłańców dostarczają wielu przykładów różnych form „nieradzenia sobie” w nowym otoczeniu. Wiąże się z tym opisywane przez nich poczucie bycia niezrozumianym (nawet przez najbliższych) i zamykanie się w sobie oraz w świecie własnych przeżyć na wiele lat. Wspominał o tym również Kazimierz Obuchowski (późniejszy profesor psychologii, który sam doświadczył wywózki do Kazachstanu): 
Są wydarzenia, a także przeżycia, obrazy, zapachy, chęci, o których ludzie nie chcą mówić lub które wypierają, uważając je za zbyt drastyczne lub intymne, a nawet zawstydzające. Są decyzje, lęki, oczekiwania, o których się nie mówi na tej samej zasadzie, na jakiej nie mówią o sobie i swoich przeżycia weterani wojenni. To tylko literatura łagrowa doczekała się strasznych w swojej otwartości wyznań, ale i tu mamy do czynienia z kilkoma nazwiskami na kilkanaście milionów ludzi (Obuchowski 1996: 428).

Mogłoby się wydawać, że inicjowanie przez różne instytucje spisywania zachowanych w pamięci przeżyć wypełni wieloletnią niszę problematyki deportacyjnej w dyskursie społecznym oraz spełni psychoterapeutyczną rolę. W wielu przypadkach okazało się to jednak niemożliwe. Z perspektywy osobistych doświadczeń odniósł się do tego również K. Obuchowski:

Gdy stwierdziłem sam u siebie, że opowiadając, posługuję się kilkoma sztampami, a pomijam pewne wydarzenia, pytałem inne osoby, czy mówią o wszystkim, chociażby osobom najbliższym. Odpowiedź była zawsze ta sama - nigdy. Są pewni, że nie zostaną właściwie zrozumiani, że sytuacja, jaka miała wówczas miejsce jest nieprzekazywalna. Nieraz po prostu chcą uniknąć ocen stawianych przez ludzi niezdolnych do wyobrażenia sobie pełni sytuacji, w jakiej te wydarzenia przebiegały. Poza tego rodzaju umotywowanymi ograniczeniami, można wyraźnie stwierdzić mechanizmy wypierania i znacznego przekształcania rzeczywistości w postaci wyraźnych konfabulacji (Obuchowski 1996: 428).

Dla ukształtowania się swoistego „syndromu zesłańca” nie bez znaczenia były konsekwencje zdrowotne poniesione przez deportowanych, które utrudniły im pełną adaptację do życia po powrocie do kraju. W pewnym stopniu „nieprzystosowanie" stawało się najbardziej charakterystyczną cechą środowisk „sybirackich”. Schorzenia stanowiły częstą przyczynę ich marginalizowania w życiu społecznym i zawodowym. Potwierdzają to również obserwacje ambulatoryjne przeprowadzone na 200 zesłańcach, których objęto opieką medyczną umożliwiającą zdiagnozowanie wielu typowych schorzeń ${ }^{20}$. Ich ogólny stan zdrowia określono jako katastrofalny, o czym świadczyła także wysoka śmiertelność badanych ${ }^{21}$. U kobiet stwierdzono dużą liczbę poronień, patologie ciąży skutkujące rodzeniem kalekich, niedorozwiniętych umysłowo dzieci (por. Klimontowicz-Kicin 1989: 7). Tego typu obserwacje potwierdzane są też przez relacje zesłańców, upatrujących źródło swoich życiowych niepowodzeń nierzadko właśnie w zrujnowanym zdrowiu. Przykładem jest poniższa wypowiedź:

${ }^{20}$ Chodzi tutaj o ambulatorium przy Zakładzie Patologii Społecznej Katedry Psychiatrii Uniwersytetu Jagiellońskiego prowadzone przez B. Monne-Dzikowską (Gierowski 2003: 87).

${ }^{21}$ W ciągu 3 lat zmarło kilkadziesiąt osób (około 50) z pozostających pod obserwacją 200 zesłańców (Gierowski 2003: 87). 
Mając taki życiorys, nie udało mi się w dalszym moim życiu, zdobyć na coś większego. Brak zdrowia hamował moje wszelkie zapędy [...]. Małżeństwo dokonane po latach nie przyniosło potomstwa z powodu niedorozwoju narządów kobiecych. Ciągłe pobyty w szpitalach, operacje z tym związane, po 12 latach pracy i 8 latach opieki nad chorą matką, nie pozwoliły nabyć praw rentowych. Poza tym ogólnie wiadomo, ze pobyt na zesłaniu, nie był mile widziany do tej pory w Polsce Ludowej. Właściwie przez 40 lat takie wspomnienia były zakazane i przynosiły ujmę wszędzie. Spotykało mnie wiele przykrości, nawet spośród przyjaciół - musieli rodzice mocno zawinić - a często nie dawano wiary moim opowiadaniom (Nowak 1989: 19).

Emanujące z wielu relacji żal i gorycz skłaniają do wniosku, że konsekwencje zesłania były znacznie szersze niż się przypuszcza. Najczęściej obserwowanymi objawami psychopatologicznymi wśród badanych zesłańców były: lęk przejawiający się przeżywaniem niezdefiniowanego niepokoju i napięcia emocjonalnego lub też konkretne obawy przed ponownym uwięzieniem i wywózką; strach przed głodem, który dotknąć może byłego zesłańca i jego rodzinę, uzewnętrzniający się poprzez gromadzenie żywności i magazynowanie różnych rzeczy; lęk przed autorytetami, władzą, mundurami; strach przed zimą, śniegiem i mrozem; mała tolerancja na niską temperaturę; przeżywanie nawrotów stresu związanego z doznanymi urazami lub ekspozycją zdarzeń przypominających różne aspekty traumatycznych doświadczeń (Gierowski 2003: 88). Wśród innych zaburzeń, będących w gruncie rzeczy symptomami PTSD (z ang. post-traumatic stress disorder), wymienia się: napady paniki, fobie, depresje, zaburzenia somatyzacyjne i związane z nadużywaniem środków psychoaktywnych, w tym alkoholu i leków oraz zmiany osobowościowe, takie jak wroga postawa wobec świata, poczucie zagrożenia i wynikająca z tego czujność, poczucie pustki i beznadziejności, wyobcowanie i emocjonalne odrętwienie, wycofanie z życia społecznego (Gierowski 2003: 45; por. Suszak 1989: 2). Ilustracją wpływu zesłańczych przeżyć na życie jednostki mogą być dwa wybrane fragmenty relacji. Jedna z kobiet pisze: „[...] wywóz na Sybir rozbił i sparaliżował całkowicie moją psychikę [...]. Bałam się nie tylko ludzi, ale nawet własnego cienia. Będąc dzieckiem nie rozumiałam tej wielkiej polityki" (Glezner 1989: 3). Pewien mężczyzna swoją egzystencję po zesłaniu przedstawił takimi słowami:

[...] wyniosłem duszę w ranach, która wkrótce zaskorupiała nieufnością, podejrzliwością, ostrożnością wobec otoczenia. Stan ten otwierał drogę, nawet wręcz prowadził do pesymizmu. Swoje życie - właściwie życie według zachowanych z wczesnej młodości pojęć - uważałem za spisane na straty. Świat mi zobojętniał, zawęził się, nie pociągał ku sobie, a raczej odpychał (Ostowski 1990: 38).

W ramach współczesnej wiedzy z zakresu psychologii i psychiatrii dobrze rozpoznano i opisano szereg odległych następstw stresu u ofiar wojny. Wśród nich do najbardziej charakterystycznych dla deportowanych wymienia się: stan chronicznej depresji, pesymistyczny stosunek do przeszłości i przyszłości oraz 
przekonanie, że tak naprawdę nikt ich nie rozumie i nie chce zrozumieć. Skutkiem tego najlepiej osoby te czują się w gronie ludzi o podobnych doświadczeniach; towarzyszy im poczucie swoistego wtajemniczenia - tylko oni wiedzą, czym był „inny świat”. Brak możliwości odreagowania doznanych krzywd powodował wieloletnie przeżywanie tragicznych wydarzeń w postaci natrętnie powracających wspomnień lub męczących, lękowych snów (por. Gierowski 2003: 89).

Jak wynika z zachowanych relacji oraz rozmów przeprowadzonych z ofiarami wojennych deportacji, ich ponowne przystosowanie do warunków życia w Polsce nie przebiegało łatwo i bezkonfliktowo. Pomimo silnej tęsknoty za krajem i nieustających marzeń o powrocie, nie uniknęli przykrości i rozczarowań. Niektórzy już nigdy nie odzyskali dawnej formy psychicznej i fizycznej, i na zawsze zostali wyłączeni z życia społecznego: przez kalectwo, nieprzystosowanie, niezaradność, nieprzychylność otoczenia. Wymownym przykładem sytuacji, w której doświadczenia wojenne i cechy osobowości stały się wyzwalaczem traumy utrudniającej ponowną adaptację do warunków życia po powrocie do kraju, jest relacja kobiety:

W życiu przeszłam wiele. W zasadzie całe mi się nie ułożyło. Nie wiem jak potoczyłyby się moje losy, gdyby nie zesłanie, ale to właśnie ten fakt wywarł największy wpływ na moje życie. Zostawiliśmy cały majątek, opuściliśmy rodzinne strony, wielu z nas zmarło z głodu i wycieńczenia, w tym moi kochani rodzice. I w imię czego?! - Pytam! Mimo tego co musiałam przejść cieszę się, że żyję, bo ileż niewinnych istnień ludzkich złożyło ofiarę Syberii? Wróciłam do Polski. Mieszkam w rozwalającym się domku. Utrzymuję się z renty [...]. Tu w Polsce zamknął się rozdział tamtych cierpień, ale też i otworzył nowy, niepowodzeń rodzinnych. Dlaczego to mnie spotkało? Całe życie przegrane. A teraz samotność. Znikąd przyjaznej ręki, dobrego, czułego serca. Za to co przeżyłam nie otrzymałam żadnej rekompensaty. Lecz czy jest nawet cena, którą można zapłacić za te krzywdy, cierpienia, ból? Czy można opłacić stratę najbliższych, którzy skonali w takich męczarniach? Czy można zapomnieć? Nie! Wspomnienia nachodzą mnie co dzień nie dając zabliźnić się ranom, a serce miota w rozpaczy. Tych dni nie da się zapomnieć (Kałuża 1989: 19).

Rozczarowanie i desperacja wypływające z niektórych narracji stanowią kwintesencję tego wszystkiego, na co zwróciłam uwagę, pisząc o skutkach wojennych przeżyć, obcowania ze śmiercią i utraty poczucia bezpieczeństwa. Równocześnie omawiane tutaj źródła są przykładem terenu badawczego, po którym trzeba poruszać się z wyjątkową rozwagą i ostrożnością. O niektórych przyczynach takiego podejścia wyżej wspomniałam - wyzwania metodologiczne i psychologiczne, niejednorodna treść, ładunek emocjonalny, wartość narracyjna i etnograficzna versus ściśle faktograficzna. Inne pozostają do rozpoznania i omówienia przez kolejnych badaczy, gdyż potencjał tych źródeł z pewnością nie został jeszcze w pełni poznany i wyeksploatowany. Liczę, że omówione tutaj dylematy pomogą badaczom tego rodzaju źródeł uniknąć przynajmniej części trudności interpretacyjnych, z jakimi ja się zmagałam. 


\section{Zakończenie}

Gdybym miała podsumować podejmowane dotychczas przeze mnie tematy badawcze, powiedziałabym, że ich wspólną cechą jest „humanistyczny wymiar indywidualnego i zbiorowego doświadczania historii i polityki". Chodzi o to, że analizowane narracje osób deportowanych oraz uchodźców i migrantów przymusowych pokazują tragiczne skutki uwikłania (często przypadkowego) pojedynczych losów ludzkich w wydarzenia, które determinują całe ich życie i stają się przyczyną osobistych i rodzinnych dramatów. „Wielka historia” $\mathrm{i}$ „wielka polityka” stają się bodźcem i tłem doświadczeń jednostkowych oraz kształtują „małe historie” (rodzinne i indywidualne). Właśnie one, postrzegane przez pryzmat narracji badanych osób, ujawniają nierzadko swoje mniej oczywiste oblicze - pozwalające dostrzec sporo szczegółów, nierzadko pozornych detali, o których wygodniej byłoby nie wiedzieć. Zdarza się, że wiedza ta przytłacza swoim ciężarem, ale nie zwalnia z odpowiedzialności świadka. Skutkiem tego trudno bywa zachować wygodny dystans "obiektywnego obserwatora” badacza-przechodnia, który zagościł w „danym temacie” (czytaj: w życiu określonej społeczności) przejściowo i na chwilę. Zdarza się, że jedynym uczciwym rozwiązaniem $w$ tej sytuacji jest zabranie głosu, to zaś na ogół oznacza zaangażowanie i utratę, tak cenionej przez antropologów, niewinności (Barley 1997).

Poszukiwanie sensu w trudnych doświadczeniach (również badawczych), a tym bardziej w porażkach, to z psychologicznego punktu widzenia ze wszech miar pozytywny objaw. Jest dowodem sprawnie działających mechanizmów obronnych i wysokiego poczucia koherencji (zrozumiałości, sensowności oraz własnej sprawczości)22 (Antonovsky 1995: 6-9). Świadczy również o umiejętności dystansowania się od zdarzeń, których jednoznaczna ocena jest trudna, oraz umiejętności określenia własnej roli w tym, co się wydarza. Czasami jest to niezbędny etap procesu poznawczego, warunkujący wgląd w obserwowane zjawisko. Zdarza się bowiem, że jest on utrudniony (zablokowany lub przysłonięty) przez emocje, napięcia i stres, towarzyszące długotrwałej i skomplikowanej relacji terenowej. Zrozumienie nie zawsze jest łatwe do osiągnięcia i bywa, że musi upłynąć sporo czasu zanim "profesjonalizm naukowy” weźmie górę i rzeczowa analiza zgromadzonego materiału będzie mogła nastąpić. Wcześniej „dokumentacja”, czy też "zgromadzony materiał" funkcjonuje czasami jako jednolity i spójny zasób osobistego doświadczenia towarzyszącego notatkom terenowym (a nie odwrotnie); scalony w jedno z przeżyciami badacza, które trudno oddzielić i wyznaczyć granicę między tym, co jest przedmiotem badawczej analizy, a tym, co stanowi intymny zasób autobiograficznych przeżyć i epizodów rozwojowych,

${ }^{22}$ Poczucie koherencji, inaczej zwane „podstawową orientacją życiową", to ogólna orientacja teoretyczna odnosząca się do poczucia dobrostanu człowieka. Wyraża się ona w stopniu, w jakim człowiek ma trwałe, choć dynamiczne przekonanie o przewidywalności środowiska wewnętrznego i zewnętrznego oraz $\mathrm{w}$ tym, że $\mathrm{z}$ dużym prawdopodobieństwem sprawy przyjmą taki obrót, jakiego można oczekiwać na podstawie racjonalnych przesłanek i że ma on na to wpływ (Antonovsky 1995, s. 11). 
czyli owych krytycznych punktów zwrotnych, kluczowych w dojrzewaniu jednostkowym. To tak, jakby dopiero co odbytą "podróż” rozpisywać na przebyte drogi: oficjalne (zawodowe) i mniej oficjalne (po godzinach, prywatne, sekretne ścieżki, którymi kluczymy, nie zawsze wiedząc, dokąd prowadzą). Może stąd bierze się opór niektórych kolegów etnografów, którzy z dużym dystansem, żeby nie powiedzieć pobłażliwością, odnoszą się do autoetnograficznych refleksji towarzyszących monograficznym opracowaniom.

Przygotowując się do pisania tego artykułu, odbyłam nawet taką rozmowę ze znajomym etnologiem, starszym i doświadczonym badaczem, który - gdy mu powiedziałam nad czym pracuję - skrzywił się nieznacznie, a przez jego twarz przemknął grymas zniesmaczenia. Nie uszło to mojej uwadze, więc poprosiłam go o wyjaśnienie. Nie bez oporów przyznał, że nigdy nie był zwolennikiem ujawniania szczegółów i niuansów warsztatowych, bowiem jego zdaniem, nie służy to dyscyplinie. Argumentował, logicznie dowodząc, że przecież medycy w opracowaniach naukowych nie mają zwyczaju opisywania swoich uczuć i przemyśleń nad okaleczonym ciałem ludzkim, które leży na stole operacyjnym. Przyznałam mu rację. Jakby tego było mało, kontynuował, sięgając po coraz to nowe przykłady świadczące, że temat ma dobrze przemyślany i ułożony niczym profesorski wywód. Na zakończenie dodał, że obawia się, iż nurt autorefleksyjny trywializuje wiele ważnych problemów badawczych i oscyluje między „martyrologią a kombatanckimi wspomnieniami przy ognisku”. Jego zdaniem, potrzeba publicznego eksplorowania własnego wnętrza po zejściu z pola badawczego kojarzy się z perwersyjnym upodobaniem do ekshibicjonizmu, który lansuje współczesna kultura popularna. Przyznam, że choć pod wieloma względami nie zgadzam się z tą opinią, riposta na tak sformułowaną krytykę wymagała namysłu i skonfrontowania się z własnymi doświadczeniami terenowymi. Skłoniła mnie ona także do rozważnego przeanalizowania własnych pobudek stojących za tym rodzajem ",antropologicznego pisarstwa" (por. Kruszelnicki 2010). Nie zmieniła jednak mojego przekonania, że transmisja wiedzy i wymiana doświadczeń z terenu służy ważnym celom, chociażby: tworzeniu „katalogów dobrych praktyk", rozwojowi technik badawczych i metod, a tym samym - doskonali profesjonalizm. Dodałabym jeszcze nie mniej ważny z mojej perspektywy czynnik: wypracowywanie efektywnych strategii radzenia sobie $z$ trudnościami i ograniczeniami (psychofizycznymi), z jakimi konfrontowani bywają etnolodzy zarówno w polu badawczym, jak i po jego opuszczeniu.

Jeśli wierzyć psychologom rozwojowym, niezbędnym elementem wzrostu człowieka i pokonywania kolejnych stadiów rozwojowych jest doświadczanie i przezwyciężanie poprzedzających je kryzysów (Erikson 2004) ${ }^{23}$. Osoba skonfrontowana $\mathrm{z}$ frustracją, niepewnością i dysonansem poznawczym ma wówczas

${ }^{23}$ Według Erika Eriksona, rozwiązanie kryzysu tożsamości jest możliwe albo przez rytualne włączenie, albo moratoryjne odroczenie (Lipska, Zagórska 2010: 14). Ogólnie jednak jego teoria rozwoju psychospołecznego zakłada, że integracja jednostkowa dokonuje się poprzez pokonywanie kolejnych kryzysów powstających w wyniku konieczności nieustannego dostosowywania się do siebie jednostki i środowiska. Rozwój dokonuje się poprzez rozwiązywanie trudności związanych ze zmianami zachodzącymi na płaszczyźnie społecznej, psychicznej i biologicznej (por. Erikson 2004). 
szansę sprawdzić się, poszerzyć zakres kompetencji i przejść w kolejną fazę dojrzałości. Poszukiwanie rozwiązań i podejmowanie decyzji to równocześnie momenty zwrotów biograficznych, które metaforycznie porównać można do zmiany trasy i środków transportu podczas "etnograficznej wyprawy”, która bywa fascynująca, lecz jej cel i efekt końcowy nie zawsze dają się precyzyjnie przewidzieć. Istotna jest bowiem gotowość podążania, przekraczania granic i otwartość na spotkania. Ilustracją opisanego tu procesu może być inny fragment wypowiedzi cytowanego już Ryszarda Kapuścińskiego:

Jesteśmy, mianowicie, odpowiedzialni za drogę. Często mamy przekonanie, że jakąś drogą idziemy czy jedziemy tylko raz w życiu, że nigdy już na nią nie wrócimy i dlatego nie wolno nam z tej podróży nic uronić, nic przeoczyć, nic stracić. Z tego wszystkiego będziemy przecież zdawać sprawę, pisać relację, opowieść czynić nasz rachunek sumienia. Dlatego podróżując, jesteśmy skupieni, mamy natężoną uwagę, wyostrzony słuch. Droga jest tak ważna, ponieważ każdy na niej krok zbliża nas do spotkania z Innym. Bo po to właśnie jesteśmy w drodze. Czy inaczej dobrowolnie narażalibyśmy się na trudy, podejmowali ryzyko wszelkich niewygód i niebezpieczeństw? (Kapuściński 2006: 12).

Kluczową w tych słowach uznanego dziennikarza i pisarza - a więc osoby spoza naszej dziedziny - jest jednak bardzo trafna i szczera odpowiedź na pytanie: po co nam to wszystko i dlaczego podejmujemy oraz znosimy te wszystkie trudy i niewygody? A przede wszystkim, czy jesteśmy świadomi roli pełnionej w życiu tych ludzi, których włączamy w nasze badania jako rozmówców, Innych, Obcych - i czy bierzemy za nią odpowiedzialność. Respons na te i kilka innych związanych z tym zagadnieniem pytań, to jednak temat na osobne rozważania najprawdopodobniej także w nurcie autoetnografii.

\section{Literatura}

Antonovsky, A. (1995). Rozwikłanie tajemnicy zdrowia. Jak radzić sobie ze stresem i nie zachorować. Przeł. H. Grzegołowska-Klarkowska, Warszawa: Fundacja IPN.

Arnett, J.J. (2007). Adolescence and Emerging Adulthood: A Cultural Approach. New Jersey: Pearson Education.

Barley, N. (1997). Niewinny antropolog. Notatki z glinianej chatki. Przeł. E.T. Szyler. Warszawa: Prószyński i Spółka.

Bielecka-Prus, J. (2018). Obcy wśród swoich. Etnografowie w polu badawczym. W: T.M. Korczyński (red.), Swój-Obcy-Wróg. Wędrówki w labiryntach kultur (s. 81-103). Gdańsk: Wydawnictwo Naukowe KATEDRA.

Cyrulnik, B. (2009). Resilience: How your inner strength can set you free from the past.London: Penguin Books.

Czapski, J. (1949). Na nieludzkiej ziemi. Paryż: Instytut Literacki.

Demetrio, D. (2000). Autobiografie. Terapeutyczny wymiar pisania o sobie, Przeł. A. Skolimowska, Kraków: Oficyna Wydawnicza "Impuls”.

Erikson, E. (2004). Tożsamość a cykl życia. Przeł. M. Żywicki, Poznań: Zysk i s-ka. 
Gierowski, J.K. (2003). Odległe następstwa stresu u ofiar systemu totalitarnego w Polsce. Próba oceny psychologicznej i psychopatologicznej. Zesłaniec, 14, 81-91.

Glezner, D. (1989). Wspomnienia, cz. IV, AN PTL, sygn. 195/s.

Hawkings, P., Shohet, R. (2006). Supervision in the Helping Professions. England: Open University Press.

Jaspers, K. (1978). Sytuacje graniczne. Przeł. A. Staniewska, M. Skwieciński. W: R. Rudziński, Jaspers, Warszawa: Wiedza Powszechna.

Juni, S. (2016). Second-generation Holocaust survivors: Psychological, theological, and moral challenges. Journal of Trauma $\mathcal{E}$ Dissociation, 17(1), 97-111, https://doi.org/1 0.1080/15299732.2015.1064506.

Kadushin, A., Harkness, D. (2014). Supervision in social work. New York: Columbia University Press.

Kałuża, L. (1989). Wspomnienia z pobytu na zesłaniu na Syberii, AN PTL, sygn. 108/s.

Kapuściński, R. (2006). Ten Inny. Warszawa: Znak.

Kaźmierska, K. (1999). Doświadczenia wojenne Polaków a kształtowanie tożsamości etnicznej, Warszawa: Instytut Filozofii i Socjologii Polskiej Akademii Nauk.

Klimontowicz-Kicin, T. (1989). Dobrowolne zestanie, AN PTL, sygn. 202/s.

Kolasa, D. (2010). Sytuacje możliwe a sytuacje graniczne w filozofii Jaspersa. Studia z Historii Filozofii, 1, 135-145.

Kacperczyk, A. (2014). Autoetnografia - technika, metoda, nowy paradygmat? O metodologicznym statusie autoetnografii. Przegląd Socjologii Jakościowej, 10(3), 32-75.

Kość, K. (2008). Żywi we wspomnieniach. Doświadczenie życia i śmierci w relacjach polskich zestańców z ZSRR (w latach 1940-1946). Wrocław: Wyd. PTL i IAE PAN.

Kość-Ryżko, K. (2013). Doświadczenie deportacji i życia na zesłaniu w relacjach Polaków wywiezionych z Kresów w latach 1940-1941. W: P. Hut, Ł. Żołądek (red.), Repatrianci i polityka repatriacyjna (s. 25-51), Warszawa: Studia BAS (Biuro Analiz Sejmowych Kancelaria Sejmu).

Kość-Ryżko, K., Czerniejewska, I. (2013a). Oblicza integracji uchodźców w Polsce. Na przykładzie analizy funkcjonowania ośrodków w Grupie i Czerwonym Borze. W: J. Balicki, M. Chamarczuk (red.), Wokót problematyki migracyjnej. Kultura przyjęcia (s. 130-155). Warszawa: UKSW, Rządowa Rada Ludnościowa.

Kość-Ryżko, K. (2013b). The Refugee Centre as a field of research, Ethnologia Polona, 33-34, 229-243.

Kość-Ryżko, K. (2013c). Etnolog w labiryncie znaczeń kulturowych. Psychologiczne wyzwania badań terenowych. W: I. Kuźma (red.), Tematy trudne, Sytuacje badawcze (s. 15-46), Łódź: Wyd. UŁ.

Kość-Ryżko, K. (2013d). Ethnologist in view of psychological challenges of the cross-cultural communication. Ethnologia Polona, 33-34, 21-37.

Kość-Ryżko, K. (2015). Tożsamość (de-)konstruowana czy (re-)konstruowana? Enkulturacja małoletnich uchodźców z Czeczenii w Polsce. Etnografia Polska, 59, 5-29.

Kość-Ryżko, K. (2016). Konstruowanie tożsamości w warunkach obcości kulturowej. Przypadek małoletnich uchodźców z Czeczenii w Polsce. Kultura i Społeczeństwo, 60(1), 93-119.

Kość-Ryżko, K. (2019). Macierzyństwo i transmisja kulturowa jako przykład wyzwań socjalizacyjnych stojących przed kobietami-uchodźczyniami w Polsce. Lud, 103, 251-274, DOI: http://dx.doi.org/10.12775/lud103.2019.13.

Kruszelnicki, W. (2010). „Antropologia jako rodzaj pisarstwa”. Krytyka tekstualna a kwestia refleksyjności w antropologii kulturowej. Teksty Drugie, 5, 140-156. 
Levine, P.A. (2017). Trauma i pamięć. Praktyczny przewodnik do pracy z traumatycznymi wspomnieniami. Przeł. M. Reimann. Warszawa: Czarna Owca.

Lipska, A., Zagórska, W. (2011). „Stająca się dorosłość” w ujęciu Jeffreya J. Arnetta jako rozbudowana faza liminalna rytuału przejścia. Psychologia Rozwojowa, 16(1), 9-21.

Malinowski, B. (2008). Dziennik w ścistym znaczeniu tego wyrazu. Wstęp i opr. G. Kubica. Kraków: Wydawnictwo Literackie.

McKinley Runyan, W. (1992). Historie życia a psychobiografia. Badania teorii i Metody. Przeł. J. Kasprzewski. Warszawa: Wydawnictwa Naukowe PWN.

Nowak I., Wspomnienia, AN PTL, sygn. 147/s.

Obuchowski, K. (1992). Autobiografia naukowa. W: T. Rzepa (red.), Historia psychologii polskiej w autobiografii, cz. I (s. 80-114). Wągrowiec: Wydawnictwo Naukowe Uniwersytetu Szczecińskiego.

Obuchowski, K. (1996). Uwagi psychologa o zsyłce w Majkainie. W: S. Ciesielski, A. Kuczyński (red.), Polacy w Kazachstanie. Historia i wspótczesność (s. 427-444). Wrocław: Wyd. Uniwersytetu Wrocławskiego.

Obuchowski, K. (2005). Porządek w piekle. Charaktery, 4, 54-55.

Ostrowski, M. (1990). Powrót z innego świata. Sybirak, 1 (4), s. 35-38.

Paluch, S. (1993). Wspomnienia zesłańca. W: E. Walewander (red.), Polacy w Rosji mówiq o sobie (s. 15-131). Lublin: UMCS.

Puławka, M. (1989). Smutne wspomnienia pobytu sześć lat na dalekiej Syberii Komi ASRR, AN PTL, sygn. 249/s.

Rudziński, R. (1980). Człowiek w obliczu nieskończoności. Metafizyka i egzystencja w filozofii Karla Jaspersa. Warszawa: Książka i Wiedza.

Suszak, H. (1989). Życiorys, AN PTL, sygn. 248/s.

Szustrowa, T. (2005). Swobodne techniki diagnostyczne (reprint z 1991). W: K. Stemplewska-Żakowicz, K. Krejtz (red.), Wywiad psychologiczny 1. Wywiad jako postępowanie badawcze (aneks). Warszawa: Pracownia Testów Psychologicznych Polskiego Towarzystwa Psychologicznego.

Tokarska, U. (2001). Narracja autobiograficzna w terapii i promocji zdrowia. W: J. Trzebiński (red.), Narracja jako sposób rozumienia świata (s. 221-244). Gdańsk: Gdańskie Wydawnictwo Psychologiczne.

Turner, V. (2005). Od rytuału do teatru. Przeł. M. i J. Dziekanowie. Warszawa: Oficyna Wydawnicza Volumen.

\section{SUMMARY}

Fieldworks initiations and the developmental dimension of the experience of "research field": Tales of war, exile and the ethnographic modus operandi

Ethnographic field research involves not only work, but also personal and existential experience. Sometimes it is routine, ordinary, and on schedule, but generally, it is not without difficulties and challenges. I discuss some of these in this article. The analysis is based on my own research experience, the common feature of which is the transgressive nature of experiences related by people and issues generally defined as "difficult". My research projects involved war victims (exiles, refugees, deportees), i.e. people who often found themselves in life-threatening situations, had experienced loss, trauma and death of their relatives. Our meetings and interviews had cognitive, psychological and developmental dimension, both in a personal and professional sense. I refer to these situations 
as "initiatory" experiences, as they constitute significant turning points in my perception of reality and my approach to research as a profession. In this paper, I discuss both methodological challenges related to research deemed difficult, as well as dilemmas related to ethnographic epistemology and the auto-ethnographic turn. My main concern here is whether and how to write about what is happening on the margins of field research and the personal struggles involved in such research.

Keywords: auto-ethnography, fieldwork, ethno-psychology, refugees, exile, methodology 